\title{
CULTURAL AND RELIGIOUS BORDERLAND IN \\ POLISH ETHNOMUSICOLOGY BEFORE AND AFTER 1989 - ON THE EXAMPLE OF THE AREAS INHABITED BY LUTHERANS
}

ARLETA NAWROCKA-WYSOCKA

The topic of the article is the peculiar situation of the researcher on the borderland. The author analyzes musicological studies conducted after 1945 in Masuria and Cieszyn Silesia - areas inhabited by Polish-speaking Lutherans, and tries to answer the questions which elements were emphasized and which were omitted or distorted.

Keywords: cultural borderland, Masuria, Cieszyn Silesia, musical tradition, Lutheran community, national identity
Članek obravnava poseben položaj raziskovalca na obmejnem območju. Avtorica analizira muzikološke študije, opravljene po letu 1945 v Mazuriji in Cieszyn Šleziji - območjih, naseljenih z luterani, ki govorijo poljsko, in poskusa odgovoriti na vprašanja, kateri elementi so bili poudarjeni, kateri izpušceni ali pa izkrivljeni.

Ključne besede: kulturna meja, Mazurija, Cieszyn Šlezija, glasbena tradicija, luteranska skupnost, nacionalna identiteta

The concept of cultural borderland referred to in the title used in sociological research has not gained much popularity among ethnomusicologists. The descriptions of regional traditions were dominated by nationalism, which caused that many elements of foreign cultures were omitted or unnoticed. ${ }^{1}$ Modern research largely uses materials collected by folklorists in the field in the post-war years. In this article I confront past and modern research attitudes presented by Polish ethnomusicologists.

In the analysis of the studies conducted in the areas of the borderland from 1945 to 1989 I will try to answer the questions about what elements were emphasized and which were omitted or distorted. The problem of confronting official political vision with beliefs of the researcher and the scientific reliability seems to be very interesting and worth examining too. The questions concerning the methods used by the researchers who were proving the purity of these ethnic areas are also important.

Searching for the answer to the question, I mainly analyzed materials collected during field research in the post-war years. The analysis of unpublished entries (reports containing descriptions of research situations, characteristics of informers, researchers' comments) was particularly helpful. The combination of these materials with published official statements allowed to show the discrepancy between the ideology implemented in the research and the complicated reality observed in the field. The most important publication that I refer to in the article is a five-volume monograph of Warmia and Mazury published at the Institute of Art of the Polish Academy of Sciences containing materials registered in 1950-1958 by

1 The fact that folklore research is dominated by concepts aimed at searching for national identity was emphasized by participants at the Ljubljana symposium in 2009. Therefore, the researchers postulated, first of all, to undertake contextual research focused on the to seek personal, social, political, national, and other identities (Klobčar 2011: 10). 
the Olsztyński team collaborating with National Institute of Art in Warsaw (Krzyżaniak and Pawlak 2002, parts 1-5).

I treat 1989 as a breakthrough date because in 1989-1991 Poland engaged in a democratic transition which put an end to the Polish People's Republic and led to the foundation of a democratic government, known as the Third Polish Republic.

\section{CULTURAL BORDERLAND}

From 1990, the notion of the borderland has become the most often quoted by Polish sociologists and ethnologists in order to describe the identity of the ethnic groups inhabiting post-war Poland (Sakson 1990; Sadowski 1995; Kurcz 1999; Jasiński and Korbel 1999).

Borderland has become an important sociological category included in the Encyclopedia of Sociology and recognized researchers initiated reflection on the need for a new subdiscipline- borderline sociology. The borderline study took on institutionalized nature. From 1992, began to appear in Bialystok the magazine Pogranicze. Studia Spoteczne, since 1996 cyclical conferences entitled Cross-border in a sociological perspective have been taking place in Zielona Góra, in 1997 the Department of Borderland Sociology was established at the University of Wrocław (Kurcz 2011: 5).

It played an extremely substantial role in the change of perceiving regions called Regained Territories. Opole Silesia, Cieszyn Silesia, Masuria and Pomerania started to be described as the areas inhabited by various ethnic groups which were subject to influences of confronting cultural patterns.

A borderland is a category understood not only as the area of the permeation of neighboring nations' cultures, which is outlined by the lines of political and administrative divisions, but also as the situation of the social-cultural contact, independent of borders and artificially imposed divisions. The cultural borderland becomes visible where the promoters of the competing cultural patterns make their presence felt (Domagała 1998: 15). Another concept often cited by Polish sociologists is highlighting three aspects of borderland research: spatial, socio-cultural and personality-cultural. According to this approach, the borderland is a peripheral area, where there is contact between ethnic or national groups and a new man and his culture are formed (Sadowski 1995).

The region of Warmia and Mazury thus perceived has become a place where international cultural, scientific, artistic and publishing projects began. Particular significance can be attributed to the "Borussia" Cultural Community established in 1990:

Multiculturalism then becomes its kind of an ideological project and a way to deconstruct the post-war national myths justifying Poland's Western and Northern Lands' return to the mother country. Within this project it becomes possible to start the dialogue with the region's multicultural past. First of all, the German 
past, yet in the programme of the group focused around the Cultural Community "Borussia" (i.e. the institution that is of some interest to the author) Germanness is understood as East-Prussianness [...]. (Domagała 2011: 81)

The popularity of the concept of borderland is also confirmed by foreign language publications. The authors cite many definitions used in political science, sociology, cultural sciences, and anthropology. However, they emphasize the common feature:

Although there is a risk of essentialising a notion such as 'border cultures', we believe that there are sufficient grounds for looking at borders generically [...]. Such a focus looks at states at the extremity of their power, at places where 'national cultures' mix and clash. The border areas are places where nations (i.e. populations who believe that because of shared culture and a common past they share the present and a common political future) must and do deal with two or more states. Nations can end at or cross these borders [...]. (Donnan and Wilson: 1999: 13)²

The notion of the borderland also turned out to be one of the most important cognitive categories for me too, because it enabled an organized and logical look at first at the complicated cultural, linguistic and religious legacy of Masuria, and then at the other regions inhabited by the Lutheran minority. Polish-speaking Lutherans have always lived in mixed cultures, denominations and languages, and they unwillingly identified themselves with the specific nationality. These are the reasons why I am going in my address not only to sketch the problem of objective transformations occurring in Polish ethnomusicology, but also to describe the peculiar situation of the researcher exploring an unknown area in the changing political reality (the beginning of my studies coincided with the nineties).

From the entire wealth of borderland cultures, I have mainly chosen areas inhabited formerly or at present by Lutherans because cultural phenomena diverge a lot from the current model, and those being characteristic of the minority were present in the literature relatively seldom. It seems that only the introduction of the notion of the cultural borderland enabled the free of limitations look at the Protestant Masurians or Cieszyn Lutherans in the sphere of the nationality, language, religion and culture.

\section{REGAINED PEOPLE - RECOVERED SONGS}

In order to understand the climate accompanying the field research right upon the completion of the warfare, one should consider the peculiar geopolitical situation of these regions,

2 Among the numerous ethnomusicological publications reporting on research conducted in the borderlands, one can mention, for example, those describing field research in the border area of Slovenia and Austria or Slovenia and Italy (e.g., Hois 2005; Pisk 2009). 
and especially the feelings of uncertainty and temporariness. They forced people to adopt ideologically explicit attitudes and imposed practical popularizing actions. The following quotation describes this situation the best:

In 1945, after centuries of separation, the Warmian-Masurian district came back into the state borders of Poland and brought to the common heritage not only the charm of its landscape, but also the irreproachable man with his diligence, rich culture which hardened in fights for national and social freeing. In People's Poland, this man was confronted with changed living conditions resulting not only from the change of the national sovereignty, but also from the victory march of the revolution [...]. Today, we must stand up to the distorted attitudes of the part of the regained people who were formed in the soured atmosphere full of venom of hatred for anything that is Polish [...] with the real character of our national culture, we have to show the beauty of our folklore, the variety of the folk art, and to prove the close relationship and the unity of this culture with the culture of regained people. (Gębik 1953: 14-15)

The manifest presented above was expressed by the Polish folklorist and the regional activist, and referred admittedly to the area of Warmia and Masuria, but it can be perceived as the motto for the field research untaken in all regained areas incorporated into the organism of the new-formed Polish People's Republic. In philosophy like this, ambiguous and interspersing cultural phenomena, which were arousing doubts, weren't accepted. The message had to be clear, so all efforts of researchers were concentrated on registering and proving the Polish national identity of these regions and their residents. The author of the statement recapitulated this action very vividly: "Regained people - Recovered songs". It was an official version which was in accordance with the line of the civil service and the ruling party, so in the first post-war years it were songbooks and sets of songs intended to be sung by folk ensembles or amateur choirs which were being published first of all.

\section{THE OFFICIAL MESSAGE AND COMPLICATED REALITY: MASURIA ${ }^{3}$}

In order to get the perfect image of Polish Masuria, problems like bilingualism of performances (Polish and the German) and the presence of the German repertoire legacy were being left unsaid. The singing was being recorded mainly in Polish, although in comments to individual songs one can find information that "the song was being sung in German"or "the

3 Masuria is north-eastern area of Poland, where at least two cultural standards clashed through the ages: the German standard connected with the presence of the Lutheran Church and propagated by Prussia and the Polish standard fostered by settlers from Mazovia and Culmland. 
female singer learnt this song at a German school". ${ }^{4}$ However, the selectivity of researchers did not concern the registered material only, but also the very performer. It appears from remarks of field researchers that they walked around the German-speaking population and settlers and were choosing people who were singing exclusively in Polish:

The songs presented here come from the Polish people who settled on this soil from time immemorial, rather than from the foreign population arriving upon completion of the warfare after 1945. The distinguishing of these materials wasnot difficult simply because during the research the oldest indigenous inhabitants were sought out. The songs were usually sung by women. Sometimes, one informant sang several dozen songs giving thus evidence of her excellent memoryand at the same time documenting the vitality of the song in spite of hard years of the captivity. (Lisakowski 1978: 257-258)

Memories of German-speaking Lutherans residing in Szczytno confirm such onesided approach of the field researchers. It resulted in a strong resentment and the feeling of rejection provoked by researchers from Warsaw who didn't want to record them because the language of the songs was not Polish, but German. ${ }^{5}$

When we look through publications and articles from the post-war twenty-year period, we do not find information about exceptionally hostile climate which was accompanying during the collection of folklore in Masuria. Instead, we more often find enthusiastic statements about the diversity of the Polish repertoire legacy, and monumental profiles of Masurian performers. However, it appears from the field notes that the situation of the contemporary researcher was far more complex and extremely difficult to assess unambiguously:

[The female singer] is anxious because of her neighbours' advice not to sing [...]. They are probably also trying to frighten her by saying that something bad is going to happen to her. As a result, when we are asking Prostka about her name, which should be entered into the protocol, she is suspecting that we want to report her [...]. People around are exceptionally nosy and hostile. It is hard to determine whether there is more hostility, jealousy caused by us coming to "poor men" by car and curiosity about the purpose, or that there is more political attitude - like in other places. Luckily, we have almost finished recording when one of neighbours who couldn't bear the tension went into the room and sat down on the chair, looking around with a murderous expression. [...] Inhospitable people around us

4 Such notes are very often included in unpublished materials and comments relating to specific recorded songs.

5 Ewa Laskowska, who was rooted in this community, studied the awareness and identity of the inhabitants of these areas. In her master's thesis she also registered the memories of her informants, (Laskowska 2001; cf. Dadak-Kozicka 2003: 283-288). 
aren'tfacilitating the continuation of our work. (Krzyżaniak and Pawlak 2002, part 1: 55$)^{6}$

The complicated situation of Masurian Lutherans is also related in short biographies of singers, which were recorded on the spot. One can learn from them about forcing people to move to nursing homes, dramas of separated families, forcible emigration to Germany and not infrequent disappointment caused by it. Notes included in the protocols show that the researchers had doubts whether information written down by them will harm the singers. In protocols, we can find traces of interventions to the individual informants' defence by the members of the team of the Institute in party committees or provincial authorities. One can suppose that the team conducting recordings was aware of exceptionally difficult political situation in Masuria. As a result, they distorted reality not only on account of the official political line, but also in order not to harm with their action the residents, who had been sorely tried by fate. This peculiar splitting between the real situation and the officially presented one was also confirmed by the then researchers who were conducting the recordings. ${ }^{7}$

The conclusion is that a few hundred Lutheran songs were recorded in Masuria (including a lot of German origin) mainly in order to prove to the authorities the vitality of Polish language which was cultivated thanks to Polish hymnals, leaflets, catechisms and prayer books. They were not denying the Lutheran faith, but they were trying to convince the official bodies that it is not dangerous. Perhaps that is why some idealized image of the folk piety of Masurians was created, with numerous common features with Catholic neighbours. The individual and unique ceremony of Masurian matins called Jutrznia mazurska na Gody was being interpreted as the Polish nativity play drawn up and adapted for the needs of Masurians. ${ }^{8}$ In the cantional repertoire, even though there were songs of the German origin, Psalms by Jan Kochanowski were being especially readily emphasized. With reference to the folk repertoire, remarks like these were obligatory: "The folk songs of Warmia and Masuria in principle adopted no German features and demonstrate a close relationship with a Polish folk song of other regions, and organically belong to the all-Poland folk music" (Lisakowski 1978: 258). In order to prove this thesis, the authors of book first of all listed shared elements of the Masovian culture, which were numerous examples of pastoral calls, tracks of the existence of the shepherd's trumpet called ligawa, and some

6 Characteristics of the performer and description of the difficult situation during recordings are included in the manuscripts of the protocols. The fragments were also published in an anthology prepared by the Institute of Art of Polish Academy of Sciences (Krzyżaniak and Pawlak 2002, part 1: 55).

7 The information on this were surfacing first of all in our informal conversations.

8 In the first publications describing the repertoire of Matins, the rite is perceived as originating from Christmas mysteries (Krzyżaniak 1978: 375). Later studies, however, emphasize the direct links with the nativity plays, i.e. a Catholic performance played at the manger (Krzyżaniak and Pawlak2002, part 5: 13). 
melodic and dance motifs. At the same time, they often ignored foreign melodies, as well as bilingual songs built in such a way that the verbal text sung in Polish were interspersed with single German words. The publications featured a few melodies with an anacrusis or a typical waltz rhythm, emphasizing the rhythmic difference of Polish melodies:

The rhythmic shape of the melody is combined with starting the melody with the beginning of the bar for "once", not from an anacrusis. [...] It is also one of the most characteristic rhythmic features of our folk songs, in contrast to the typical anacrustic system of West European music, especially German. (Lisakowski 1978: 265)

This conduct to some extent resembled the attitude of German authors such as Karl Plenzat (1918), Hedwig Borowski and Ewald Lukat (1930) or Joseph Müller-Blattau and Artur Jeziorowski (1934) who were publishing small collections of Masurian folk songs in the interwar period. ${ }^{9}$

Such a view on the Masurian culture lasted in principle all the way until a turning point after which it is finally possible to speak openly about Masurian identity and to describe exactly all complex political and public processes. In sociology, as I mentioned at the very beginning, these new political conditions were used almost immediately, but in ethnomusicology the change of a viewpoint was a much slower process. A monograph on Warmia and Masuria published in 2002 by the Institute of the Art of the Polish Academy of Sciences is an example of the publication reflecting the transitional state. It was prepared long before 1989 and introduced both traditional view, which was emphasizing the Polish national identity of the regions and residents, and a lot of elements which did not fit in with that perfect image (Krzyżaniak and Pawlak 2002, parts 1-5).

\section{REGIONALISM AND OMITTED FOREIGN INFLUENCES - CIESZYN SILESIA}

The situation described in Masuria reminded a lot the one present in Lower or Upper Silesia, including Cieszyn Silesia. The difference was that the communities inhabiting these regions were more diversified with regard to faith. While a Lutheran faith was a characteristic of the identity of Masurians, the Silesianness combined coherently with no faith.

It was only Cieszyn Silesia where the population of Lutheran faith prevailed. On account of its history, which was at first connected with the Piasts' dynasty, next with Prussia, Austrian Empire and in the end with the Second Republic of Poland, the area of

9 German researchers, in order to obliterate relationship with the Polish national identity, were translating the texts, distorting the order of measure and rhythm by replacing the rhythms of mazurek with upbeat or adapt tunes to the bars with mixed metre. 
Cieszyn Silesia has always been recognised as the borderland, but rather in the geographical meaning. The studies after 1945, unlike those carried out in Masuria, were concentrated above all on regional elements. As it was expressed by Jerzy Drozd, the author of one of the first songbooks published after the war: "The intense folk movement in Beskids Silesia has been lacking the regional songbook for a long time" (Drozd1978: 5). In contrast with Masuria, in Cieszyn Silesia, which was integrated into Poland as far back as before the outbreak of the World War II, the thorough enough field research was commenced already in the interwar period (Ligęza and Stoiński 1938). The regionalists who were preparing publications after 1945 were referring to this legacy. They did not have to prove the Polish national identity in this region unlike on the other side of Olza River because of the political dividing Cieszyn Silesia into the Polish part and the Czech one, which was called Zaolzie. It seems puzzling that in field research carried out in the fifties in the Cieszyn area as part of the Action of Collecting the Folklore, during which over 10 thousand songs were recorded, only a few were religious ones.This situation is strange in so far as the person conducting the recording, Jan Tacina, was a Lutheran himself, and knew very well the repertoire of his church also in the local version (he was the author of the chorale book, as well as he voiced his opinion on folk way of singing hymns). What is more, from certificates of the singers we also know that many of them were of Lutheran faith. Perhaps the reason for this omitting the religious repertoire was its "non-Polish" character, or perhaps the conviction that one should concentrate exclusively on the recording of the folk repertoire? The belief that religious songs from Cieszyn Silesia are of a mixed nature was shared by the Lutherans themselves. It was very clearly expressed by Karol Hławiczka, an outstanding hymnologist and folklorist:

In the region of Cieszyn Silesia, which has the second biggest population of Polish Lutherans, in the Hymnal by Heczko there is also quite a lot of songs signed as "Old Polish" ones, but the Czech and Slovak songs firmly affected it because evangelicals in Silesia up to its publishing lacked their cantional and were singing songs from the Slovak hymnalCithara Sanctorum by Jerzy Trzanowski from Trzanowice in Zaolzie. (Hławiczka 1963: 373-374)

\section{THE NOTION OF BORDERLAND - A NEW STANDPOINT}

The quoted examples of positions of researchers expressed by them in the area of Masuria and Cieszyn Silesia, in spite of seeming differences, have a lot of common characteristics. Above all, they concentrate on some beforehand adopted vision or a stereotype to which suitable elements of the culture are adjusted and unsuitable ones are omitted. The introduction of the notion of borderland permitted to move the centre of gravity from formulating a closed, stereotyped vision of culture to an open and concentrated on an identity one. The 
criteria which were taken into consideration in determining the identity were the following: shared territory, language, origin, religion, shared experience, customs, and relative isolation from strangers.

The notion of the cultural borderland was acquired by the next generation of musicologists, who had neither the burden of wartime memories nor political and ethnic prejudice, could try to show the entire cultural panorama of this region, or clear its debt to ancestors by devoting the separate study to the omitted group (monograph on the culture of German-speaking Lutherans made by Laskowska 2001). The experienced and distrustful community isolated itself hermetically from researchers from the outside, therefore they could solely to try to interpret the gathered facts anew (Nawrocka-Wysocka 2002, 2004). However, representatives of the omitted groups have spoken more and more often showing finally the facts openly and without concealments.

As I mentioned before at the beginning, I assess the category of the cultural borderland as particularly helpful in my own research on the musical tradition of Lutheran communities. I used it both in the description of groups which disappeared a long time ago, so the knowledge about their tradition is fragmentary (Slovincians from Pomerania, and Lutherans from Silesia and Greater Poland), as well as in the description of the groups whose tradition was registered almost at the last moment (Masurians) or those which I was observing personally in the field (Cieszyn Silesia). Such changed viewpoint allowed dealing with kinds from the outside of the genetically understood folk musical culture (religious and popular songs, legends). Also, it was at last not necessary to leave unsaid and to conceal the obvious or only assumed foreign influences (German, Czech, Slovak and the like).

As an example of the new interpretation I will quote aforementioned ceremony of Masurian Matins called Jutrznia mazurska na Gody regarded by many researchers as remains of the Catholic nativity play. The significant for it the practice of alternatim (the singing of subsequent lines of the song by four choirs standing in different corners of the church) was characteristic of the medieval dramatic form of Quempas (it derived its name from the first line of the Latin Quem pastores laudavere and was documented for the first time in the15th century in a manuscript from Hohenfurt). The liturgical application of the alternatim is confirmed by two sources: Ordo cantionum ecclesiasticarum from Dessau (1545) and Missale from the Wittenberg (1589) (Ameln 1966: 55). The form was probably adopted by Mazurians and according to their needs set into appropriate decorations. There are evidences of the practice of Quempas coming from various regions of Germany. Also, in some regional varieties it is possible to discern certain analogies in the way of selecting props and the decoration. The repertoire of this ceremony, which lasted for many hours, was very diverse because it included, apart from newer verse songs, translations of Latin cantiones (Dies est laetitie, In dulci jubilo), hymns, and the translations of allegorical songs created at the beginning of the Reformation (for example Wachet auf ruft uns die Stimme by Philipp Nicolai) adopting characteristic Barform, coming as early as from the tradition of singings of Minnäsingers. 
The introduction of the category of the cultural borderland into the descriptions of musical phenomena in Cieszyn Silesia allowed to notice the unusual symbiosis of Silesianness and Lutheran faith, and to portray the musical repertoire of Cieszyn Lutherans not selectively, but as a whole. It enabled also to look truly at the Czech, Slovak and German cultural legacy passed on through regional cantionals and hymnals.

Today, there is a lot of a criticism of the pluralism and preferring ethnicity to the sense of nationality. All the more so, one should appreciate the fact, that at the beginning of the nineties these omitted or shown in the false light communities were perceived as more significant. Also, the period after 1989 created a comfortable situation for the researchers because they didn't have to dither over what and how they are allowed to study, but over what and how they should do it. This period enabled as well a free flow of ideas and the possibility of participating in international forums, which has been of great importance.

\section{REFERENCES}

Ameln, Konrad. 1966. Quem Pastores Laudavere. Jahrbuch für Liturgik und Hymnologie 11: 45-88.

Borowski, Hedwig, and Ewald Lukat. 1930. Masurische Volkslieder. Königsberg in Preussen: Gräfe und Unzer.

Dadak-Kozicka, Katarzyna. 2003. O zamieraniu i odradzaniu kultur muzycznych na przkładach folkloru północno-wschodniej Polski. In: Elżbieta Wojnowska et al. (eds.), Europejski repertuar muzyczny na ziemiach Polski. Warszawa: Związek Kompozytorów Polskich, 279-297.

Domagała, Bożena. 1998. Z problematyki tożsamości obszarów pogranicza. In: Bożena Domagała and Andrzej Sakson (eds.), Tożsamość kulturowa spoteczeństwa Warmii i Mazur. Olsztyn: Ośrodek Badań Naukowych im. Wojciecha Kętrzyńskiego, 12-22.

Domagała, Bożena. 2011. Wielokulturowość na pograniczach: Polityka i ideologia (na przykładzie Warmii i Mazur). In: Zbigniew Kurcz (ed.), Polskie pogranicza w dobie przemian. Vol. 2. Wałbrzych: Wydawnictwo WWSZiP, 67-81.

Donnan, Hastings, and Thomas M. Wilson. 1999. Borders: Frontiers of Identity, Nation and State. Oxford: Berg.

Drozd, Jerzy. 1978. Cieszyński śpiewnik regionalny. Bielsko Biała: Urząd Wojewódzki Wydziału Kultury; Katowice: Wojewódzki Ośrodek Kultury.

Gębik, Władysław. 1953. Pieśni ludowe Mazuri Warmii. Olsztyn: Wydział Kultury Prezydium Wojewódzkiej Rady Narodowej.

Hławiczka, Karol. 1963. Melodie polskie w Kancjonale Mazurskim. Komunikaty Mazursko-Warmińskie 3: 333-374.

Hois, Eva Maria. 2005. Folk Music Research in 'Old' Austria and in 'New' Europe Concerning Understanding Between Nations and National Endeavors. Traditiones 34 (1):23-34. DOI: https://doi.org/10.3986/ Traditio2005340102.

Jasiński, Zenon, and Jan Korbel (eds.). 1999. Zderzenia i przenikanie kultur na pograniczach. Opole: WSP.

Klobčar, Marija. 2011. Real and Virtual Spaces of Revisiting the Question 'What to Do with Folklore?' Traditiones 40 (4): 5-15. DOI: https://doi.org/10.3986/Traditio2011400301. 
Krzyżaniak, Barbara. 1978. Obrzędy i zwyczaje Warmii i Mazur. In: Maria Drabecka et al. (eds.), Folklor Warmii i Mazur. Warszawa: Centralny Ośrodek Metodyki Upowszechniania Kultury, 365-532.

Krzyżaniak, Barbara, and Aleksander Pawlak. 2002. Warmia i Mazury. Parts 1-5. (Series Polska pieśń i muzyka ludowa, źródła i materiały, ed. Ludwik Bielawski). Warszawa: Instytut Sztuki PAN.

Kurcz, Zbigniew (ed.). 1999. Pogranicze z Niemcami a innepogranicza z Polski. Wrocław: Wyd. Uniwersytetu Wrocławskiego.

Kurcz, Zbigniew (ed.). 2011. Polskiepogranicza w dobieprzemian. Vol. 2. Wałbrzych: Wydawnictwo WWSZiP.

Laskowska, Ewa. 2001. Folklor Mazurów ewangelickich okolic Szczytna: Tradycja i wspótczesność, praca magisterska. Master thesis. Warszawa: Uniwersytet im. Fryderyka Chopina w Warszawie.

Ligęza, Józef, and Stefan Marian Stoiński. 1938. Pieśni ludowe zpolskiego Śląska: Pieśni balladowe o zalotach i mitości. Vol. 2. Kraków: Polska Akademia Umiejętności: Wydawnictwa Śląskie.

Lisakowski, Jarosław. 1978. Charakterystyka pieśni i muzyki. In: Maria Drabecka et al. (eds.), Folklor Warmii i Mazur. Warszawa: Centralny Ośrodek Metodyki Upowszechniania Kultury, 257-281.

Müller-Blattau, Joseph, and Artur Jeziorowski. 1934. Masurische Volkslieder. Berlin und Leipzig: Verlag Walter de Gruyter.

Nawrocka-Wysocka, Arleta. 2002. Śpiewy protestanckie na Mazurach. Warszawa: Instytut Sztuki PAN.

Nawrocka-Wysocka, Arleta. 2004 Protestant songs in Mazury: The repertoire of a Borderland. In: Ursula Hemetek et al. (eds.), Manifold Identies: Studies on Music and Minorities. London: Cambridge Scholars Press, 246-256.

Pisk, Marjeta. 2009. Folklore Studies and Presentations of Folk Song Traditions of Slovenian-Friulan Border Area. Traditiones 38 (1): 117-130. DOI: https://doi.org/10.3986/Traditio2009380108.

Plenzat, Karl. 1918. Der Liederschrein: Hundertundzehn deutsche, litauische und masurische Volsklieder aus Ostpreussen m. Lautensatz. Leipzig: Friedrich Hofmeister.

Sadowski, Andrzej. 1995. Socjologia pogranicza. In: Andrzej Sadowski (ed.), Wschodnie pogranicze w perspektywie socjologicznej. Białystok: Wydaw. Ekonomia I Środowisko, 12-19.

Sakson, Andrzej. 1990. Mazury spoteczność pogranicza. Poznań: InstytutZachodni.

\section{KULTURNA IN RELIGIOZNA MEJA V POLJSKI ETNOMUZIKOLOGIJI PRED IN PO LETU 1989 - NA PRIMERU OBMOČIJ, NASELJENIH Z LUTERANCI}

$V$ sociologiji je meja območje, kjer se križajo različni kulturni vplivi in se pojavljajo napetosti med kulturno-civilizacijskimi vzorci. Ta zapletena vprašanja so dolgo časa presegala interese folkloristov na Poljskem. Ti so predvsem preučevali pretežno etnično poljsko folkloro, kar je bilo razumljivo tudi zaradi vojne, ki je vplivala na prej zbrano gradivo. Drug pomemben razlog so bile ideološke omejitve, ki jih je uvedla država, ko je sponzorirala tekoče raziskave. Kjer je šlo za t.i. Poljski "povrnjena ozemlja" (Ziemie Odzyskane), je bila naloga raziskovalcev dokazati 
poljske korenine. $V$ teh prizadevanjih so zato raziskovalci navadno ignorirali ali spregledali sestavine, ki niso povsem ustrezale pričakovani podobi. Takšno stanje je bilo značilno za Šlezijo, Cieszyn Šlezijo in Mazurijo, kjer so npr. luterani, ki govorijo poljsko, vedno živeli v prepletu kultur, poimenovanj in jezikov in se praviloma niso radi identificirali le z eno narodnostjo.

$Z$ današnjega vidika so pomembna naslednja vprašanja: katere metode so raziskovalci uporabili, da bi dokazali čistosti teh etničnih območij; katere elemente so izpuščali ali prilagajali posebnim predpostavkam ter zakaj so se raziskovalci praviloma dokumentirali skoraj izključno ljudski repertoar?

Delne odgovore na ta vprašanja omogoča registrirano arhivsko gradivo v obliki protokolov in komentarjev raziskovalcev. Veliko jih ni bilo razkritih in so ostali zaščiteni pred cenzuro. To velja npr. za podatke o nemškem repertoarju in o informatorjih, ki pripadajo protestantski cerkvi. Nekatere sledi postopkov zagotavljata tudi izbor in razvoj repertoarja. Med snemanjem so bile $v$ 50. in 60. letih skoraj povsem izpuščne religiozne pesmi. Učinek poudarjanja nacionalnih elementov je med drugim viden tudi v prilagajanju melodij, značilnih za tujo folkloro, ritem, običajen za poljske melodije; poudarek je bil tudi na ustrezni interpretaciji ljudskih obredov. Ideološke omejitve, podrejene oz. prilagojene nacionalnemu dojemanju obmejnih območij, so izkrivile njihovo resnično podobo. Danes labko brez predsodkov razberemo, da se je tamkajšnja kulturna identiteta oblikovala na križiščih različnih zgodovinskih in nacionalnih procesov.

Dr. Arleta Nawrocka-Wysocka

The Institute of Art, Polish Academy of Sciences

Ul. Długa 28, PL - 00-238 Warszawa, Poland arletanw@gmail.com, arleta.nawrocka-wysocka@ispan.pl 